Meta

Journal des traducteurs

Translators' Journal

\title{
Investigating Translators' Work-related Happiness: Slovak Sworn and Institutional Translators as a Case in Point
}

\section{Klaudia Bednárová-Gibová et Branislav Madoš}

Volume 64, numéro 1, avril 2019

URI : https://id.erudit.org/iderudit/1065335ar

DOI : https://doi.org/10.7202/1065335ar

Aller au sommaire du numéro

Éditeur(s)

Les Presses de l’Université de Montréal

ISSN

0026-0452 (imprimé)

1492-1421 (numérique)

Découvrir la revue

Citer cet article

Bednárová-Gibová, K. \& Madoš, B. (2019). Investigating Translators'

Work-related Happiness: Slovak Sworn and Institutional Translators as a Case in Point. Meta, 64(1), 215-241. https://doi.org/10.7202/1065335ar
Résumé de l'article

L'article rend compte d'une enquête effectuée au sein d'un projet d'ensemble visant à examiner, dans divers contextes, le bonheur professionnel des traducteurs, sujet largement négligé par les traductologues contemporains. Cette étude de cohorte pilote cherche à saisir la perception du bonheur dans deux groupes de traducteurs considérés de haut niveau - traducteurs assermentés slovaques et traducteurs slovaques travaillant pour l'UE. Pour atteindre l'objectif fixé, des perspectives comparatives et causales sont mises en place. Les données issues de questionnaires remplis par 115 traducteurs appartenant aux deux groupes $(83+32)$ en question sont soumises à une analyse quantitative comprenant une analyse descriptive et une analyse de corrélation. La perception que les répondants ont de leur bonheur au travail est examinée et comparée à partir de leurs réponses aux questions concernant principalement des variables inhérentes au statut social et des paramètres de prestige professionnel. Sur la base des données obtenues, sept hypothèses sont formulées et vérifiées au moyen de méthodes de recherche quantitatives exploitant des tableaux de contingence. Bien que dans la plupart des cas nos découvertes ne corroborent pas les hypothèses et permettent de découvrir plusieurs différences cruciales entre les deux groupes, les analyses font également apparaître certains points communs. Les résultats de l'analyse quantitative sont examinés en détail.
Ce document est protégé par la loi sur le droit d'auteur. L'utilisation des services d'Érudit (y compris la reproduction) est assujettie à sa politique d'utilisation que vous pouvez consulter en ligne.

https://apropos.erudit.org/fr/usagers/politique-dutilisation/ 


\title{
Investigating Translators' Work-related Happiness: Slovak Sworn and Institutional Translators as a Case in Point
}

\author{
KLAU DIA BEDNÁ ROVÁ-GIBOVÁ \\ University of Prešov, Prešov, Slovakia \\ klaudia.gibova@unipo.sk
}

BRANISLAV MADOŠ

Technical University, Košice, Slovakia

branislav.mados@tuke.sk

\begin{abstract}
RÉSUMÉ
L'article rend compte d'une enquête effectuée au sein d'un projet d'ensemble visant à examiner, dans divers contextes, le bonheur professionnel des traducteurs, sujet largement négligé par les traductologues contemporains. Cette étude de cohorte pilote cherche à saisir la perception du bonheur dans deux groupes de traducteurs considérés de haut niveau - traducteurs assermentés slovaques et traducteurs slovaques travaillant pour l'UE. Pour atteindre l'objectif fixé, des perspectives comparatives et causales sont mises en place. Les données issues de questionnaires remplis par 115 traducteurs appartenant aux deux groupes $(83+32)$ en question sont soumises à une analyse quantitative comprenant une analyse descriptive et une analyse de corrélation. La perception que les répondants ont de leur bonheur au travail est examinée et comparée à partir de leurs réponses aux questions concernant principalement des variables inhérentes au statut social et des paramètres de prestige professionnel. Sur la base des données obtenues, sept hypothèses sont formulées et vérifiées au moyen de méthodes de recherche quantitatives exploitant des tableaux de contingence. Bien que dans la plupart des cas nos découvertes ne corroborent pas les hypothèses et permettent de découvrir plusieurs différences cruciales entre les deux groupes, les analyses font également apparaître certains points communs. Les résultats de l'analyse quantitative sont examinés en détail.
\end{abstract}

\section{ABSTRACT}

This paper reports on an investigation which is part of a comprehensive project aimed at investigating translators' work-related happiness in various contexts, a subject largely under-researched in contemporary translation studies. The purpose of this pilot cohort study is to determine the perceptions of happiness in two presumably high-profile groups of translators-Slovak sworn translators and Slovak EU translators. To accomplish the aim, comparative and causal perspectives are used. The quantitative analysis, comprising descriptive and correlation analysis, involves data from questionnaires completed by a total of 115 translators belonging to the two groups $(83+32)$. The respondents' perceptions of their work-related happiness are examined and compared, based on their responses to questions revolving primarily around social status variables and parameters of occupational prestige. Based on the gained data, seven hypotheses are tested with quantitative research methods employing contingency tables. Although our findings largely do not corroborate the hypotheses and lead to the identification of crucial differences between the two groups, the analyses also allow us to identify some commonalities. The results of the quantitative analysis are discussed in detail. 


\section{RESUMEN}

Este artículo informa de una investigación que es una parte de un proyecto más amplio dirigido a la investigación de la felicidad laboral de los traductores. Este tema cuenta con muy pocos estudios en la traductología contemporánea en diferentes contextos. El propósito de este estudio piloto de cohorte es determinar la percepción de la felicidad en dos grupos de traductores considerados de alto nivel profesional - los traductores jurados eslovacos y los traductores eslovacos de la UE. Para lograr este objetivo, utilizamos el punto de vista comparativo y causal. El análisis cuantitativo incluye un análisis descriptivo y correlativo de los datos obtenidos de cuestionarios respondidos por 115 traductores pertenecientes a los dos grupos $(83+32)$. Analizamos y comparamos la percepción de la felicidad laboral en base a las respuestas relacionadas ante todo con las variables de estatus social y los parámetros de prestigio profesional. Sobre la base de los datos obtenidos probamos siete hipótesis por medio de métodos de investigación cuantitativos con empleo de tablas de contingencia. Aunque nuestras conclusiones en gran parte no corroboran las hipótesis e indican algunas diferencias cruciales entre los dos grupos, los análisis también nos permiten identificar algunas similitudes. Los resultados del análisis cuantitativo son discutidos detalladamente.

\section{MOTS-CLÉS/KEYWORDS/PALABRAS CLAVE}

traducteur, bonheur au travail, traducteur assermenté, traducteur pour l'UE, analyse quantitative

translator, work-related happiness, sworn translator, EU translator, quantitative analysis traductor, felicidad laboral, traductor jurado, traductor de la UE, análisis cuantitativo

Happiness does not come from doing easy work but from the afterglow of satisfaction that comes after the achievement of a difficult task that demanded our best.

(Rubin: 1976) ${ }^{1}$

\section{Introduction}

The sociological turn in translation studies (hereafter TS) over the past decade or two has been accompanied by a growing interest in translation as a profession and translators as a professional and social group. In this light, Chesterman (2009) called for the establishment of translator studies with a sharpened focus on the figure of the translator rather than on translations as texts, reflecting a paradigmatic change in TS and new research directions. In this context, the topic of the present paper-the translator's work-related happiness-is beginning to arouse scholarly attention after having been largely marginalized in empirical TS research. Although still rarely the central focus of single publications, over the past few years some TS scholars have started to touch on this issue in their studies, albeit within broader analyses (for instance, Sela-Sheffy and Shlesinger 2008; Katan 2009, 2011; Setton and Guo Liangliang 2011; Liu 2013; Hubscher-Davidson 2016). With this paper, we aspire to shed more light on the much under-researched topic of the translator's happiness. Though one might object that the topic of happiness has long been only a "playground for speculative philosophy" (Veenhoven 1997: 29), in the past decades it has become a focus of research in social sciences; now it offers uncharted research avenues for TS.

The literature review to follow in section 2 indicates that none of the recent studies have systematically and exhaustively addressed the topic of translator happiness. To start to fill this gap, we have embarked on a comprehensive project with the longterm aim of investigating translators' happiness in various contexts. The focus of this 
study are two presumably high-profile groups of translators, Slovak sworn translators and Slovak EU translators, both of whom carry out specific sorts of legal translation. Their choice can be justified by the fact that most studies so far have been contextualized in the "discourse of lamentation." Prior studies consistently emphasize translators' complaints about their lack of societal recognition, low remuneration, feelings of powerlessness, submissiveness, and invisibility (see Sela-Sheffy and Shlesinger 2008; Katan 2009, 2011; Abdallah 2010; Dam and Zethsen 2009, 2011, 2014, 2016). Against this backdrop, it is particularly intriguing to look at two groups that are widely believed to enjoy somewhat privileged positions among translators. This could also help us ascertain whether work-related happiness is linked to certain occupational parameters. Moreover, to the best of our knowledge no quantitative enquiry into translator happiness has been carried out on the two target groups. This makes our pilot cohort study the first of its kind in Slovakia. Lastly, the selection of the two groups from the translators' continuum was also motivated by one of the author's long-term interest in legal and EU translation.

Although the groups of translators selected for this study represent only a fraction of presumably strong, professional profile translators, we hope that the findings can inspire high-profile translators on the international scene. At the same time, the study should serve as a launching pad for other quantitatively oriented comparative analyses for translators of other nationalities and micro-habitus. Last, but far from least, it increases our perceptions and knowledge of the translators' identity and profession.

\section{Research context}

On a deeper level, the study of the professional status and identity of translators only started in the second half of the 2000s (see Snell-Hornby 2006). With a sharpened sociological eye in TS, a strong interest in the status of translators as well as the issues of their identity, role, and professionalism have emerged in the work-in-progress by Dam and Zethsen $(2008,2009,2011,2014,2016)$. Using different groups of translators in Denmark, they investigated how translators' occupational status was perceived, based on parameters of occupation prestige, such as remuneration, education/expertise, power/influence, and visibility. Similarly, in China and Korea, fairly intensive research has been devoted to professional status, translating conditions, job-related satisfaction, and translators' and interpreters' expectations (Setton and Guo Lianglang 2011; Liu 2011, 2013; Volland 2014). In Israel, Sela-Sheffy and Shlesinger $(2008,2011)$ have launched a nationwide project that maps translators' and interpreters' identities in different sectors, also focusing on literary translators. In view of a peripheral, poorly paid and low-status occupation, Katan $(2009,2011)$ offers a worldwide survey of translators' and interpreters' perceptions of their work and job-related concerns in 25 countries (excluding Slovakia) with approximately 1,000 respondents. From yet another perspective, Koskinen's (2009) ethnographic study of the workplace identified active agency in networks of translators and interpreters as they define their professional status and shape their social settings. This body of work, as described above, has culminated in the publication of a volume entitled Identity and Status in the Translational Professions (Sela-Sheffy and Shlesinger 2011). An up-to-date collection of papers on the topic The Translation Profession: Centres 
and Peripheries, edited by Dam and Koskinen in 2016, also appeared as a special issue of JoSTrans.

In Slovakia, a comprehensive survey of what translators do, seeking answers to determine who translates what, how, and under what circumstances (barring translators' happiness) has been conducted by Djovčoš (2012; 2014). Using largely the same methodology with a 5-year-retrospective comparison, Djovčoš and Šveda (2017) provided an in-depth analysis of current conditions and tendencies in the Slovak translation and interpreting market.

Although every piece of the research described above deals more or less with a study of translators (or interpreters) as specific professional groups, their sense of professional selves or status struggles, one important aspect of their professional life has been relatively little discussed so far: work-related happiness. In searching for a niche in sociologically minded TS research, this topic, with reference to the occupational context, could contribute to filling the lacuna. The importance of happiness in our professional lives can hardly be overstated because, whether we like it or not, work constitutes a major part of our lives. Thinking about happiness in a work-related perspective for an occupation that is nowhere near the top of the professional prestige ladder (see Katan 2009, 2011; Henter 2016) may open riveting avenues for the study of how human agency creates and changes its social environment.

Overall, the scant empirical research that has been conducted so far shows that most surveys on happiness or job satisfaction are found in the area of interpreting, not in translation (see for example Tryuk 2007; Choi 2007; Pöchhacker 2009; Neff $2011^{2}$ ). The overall picture which emerges is that interpreters are by and large satisfied with their profession. ${ }^{3}$ However, in sharp contrast to interpreters, Hermans and Lambert, who carried out research on job satisfaction among translators in Belgian business environments, suggest that translating is not conducive to happiness:

[...] the general view is that there is no reason to spend much money on someone who just happens to know the necessary languages or who enjoys language games anyway. Such a job can be done by an assistant manager or secretary, or in certain cases even by a talented engineer, during working hours. It can also be done over the weekend or at home, when the 'real job' is over. As a result, no partner is happy: neither the commissioner of the translation nor those who perform it on the basis of a gentle (wo)man's agreement. (Hermans and Lambert 1998/2006: 155)

Despite this grim view of the translator's situation, a few surveys suggest, to the contrary, that translators seem rather satisfied in their professional roles. To illustrate this, in Katan's $(2009,2011)$ global online surveys of translators' self-concept, translators, quite surprisingly, confirm that despite being frequently ranked as lower autonomy professionals (LAPs), they are 'pretty' (50\%) or 'extremely' (21\%) satisfied with their jobs (Katan 2009: 148-149). Similarly, Setton and Guo Liangliang (2011) did research into translators' and interpreters' self-perceptions and job satisfaction in Shangai and Taipei. They report that the respondents were either 'satisfied' or 'very satisfied' with their work while as few as $5 \%$ of the informants were 'dissatisfied' even though interpreters were "clearly happier with their jobs overall" (Setton and Guo Liangliang 2011: 102).

The job-related happiness of translators has also been investigated by Liu (2011, 2013), but only as a dependent variable assessing translators' visibility. Although she provides a detailed metric to evaluate job-related happiness among Chinese transla- 
tors in Greater China, she actually provides no research results for the sources of their happiness.

Another contribution to the research mosaic under discussion comes from Dam and Zethsen (2016). In work that partly overcomes Liu's shortcoming, they investigate the paradox of the translator's profession by exploring the sources of translators' job satisfaction and the factors "that motivate translators to stay in a profession that seems to be offering substandard working conditions" (Dam and Zethsen 2016: 174). They argue that the translators are well aware of their cultural capital (in Bourdieu's terms) and for this reason they see translation as "exciting and satisfying," "varied, stimulating and never boring" or as an "intellectual and creative challenge." Their expertise and skills of which they are so proud often compensate for the lack of the translator's symbolic capital, which is an intriguing finding in today's money-based world (Dam and Zethsen 2016: 180-181).

More recently, translators' job satisfaction has been examined through ergonomic studies and affective translation psychology. With respect to the former, ergonomics, which provides insights into physical, cognitive, and organizational aspects that impinge on translations, emphasizes a connection between, on the one hand, the ergonomic conditions of the workplace, tools and resources, workflow, and organization, and, on the other hand, the productivity, health, and job satisfaction of translators (see Ehrensberger-Dow 2015, 2017; Ehrensberger-Dow, Hunziker Heeb, et al. 2016). With regard to the latter, Hubscher-Davidson (2016) examines the relationship between the trait "emotional intelligence" (trait EI) and job satisfaction, career success, and literary translation experience, finding some significant correlations. According to Hubscher-Davidson (2016: 147-148), trait EI could be an important predictor of translators' job satisfaction: translators rated high for trait EI, being more skilled at expressing their emotions, could be more satisfied at work in comparison to translators rated low for trait EI, who are less able to cope with their emotions when facing emotionally difficult situations in translating.

Finally, translator satisfaction from the point of view of human resources management has been studied by Rodríguez-Castro (2015). In an attempt to understand translators' happiness at work in the contemporary language industry, she devised a detailed instrument for gauging task and job satisfaction among translators. Although the instrument measures direct and indirect tasks as well as job satisfiers and dissatisfiers, its main drawback is the length of the survey underlying the proposed constructs of task satisfaction and job satisfaction that can be used as a baseline for future studies.

\section{Happiness and profession}

\subsection{Happiness: points of departure and perspectives}

Over the past decades, the subject of happiness has become an issue in philosophy, psychology, social sciences, and even medical research. The majority of studies on the subject are part of a wider field of enquiry, commonly referred to as "quality of life" (QOL). Generally, happiness can be viewed as "subjective enjoyment of life as a whole" (Veenhoven 1997: 22) and in this sense it is not an elusive concept. In psychology, happiness is "a state of well-being characterized by dominantly agreeable emotions ranging in value from mere contentment to positive felicity" (Warr 2007: 20). 
Although it may be true that there can be as many perceptions of happiness as there are people or points of view, for the purpose of this study, happiness is defined as the degree to which a translator evaluates the overall quality of their professional life positively. In other words, work-related happiness means how much the translator takes pleasure in the working life they lead. According to Veenhoven (1997: 2), happiness is one of the indicators of "apparent" quality of life and it reveals how well people thrive. Conceptually, it may be used synonymously with terms such as life satisfaction, which underscores the subjective nature of the concept, or subjective well-being, which may also imply specific discomforts or passing moods (Veenhoven 1997: 5). Warr (2007: 7), however, points out that the term happiness tends to be avoided by most academic psychologists and preference is given to either affect or well-being. As both terms are often used to examine a single, short episode, that is to say "an immediate reaction to an input from the environment" (Warr 2007: 11) while our study homes in on the long-term state, we use the term happiness. Moreover, we do not rely on the term job satisfaction because job satisfaction, drawing on Schaffer (1953: 3), can be interpreted to imply that an individual's needs are fulfilled. ${ }^{4}$

Since the 1960s, several scales have been developed to measure happiness, such as the Subjective Happiness Scale (SHS), the Positive and Negative Affect Schedule (PANAS), Diener's Satisfaction with Life Scale (SWLS) or Rodríguez-Castro's multifaceted instrument (2015), to mention just a few. Although the measurement of happiness by the IWP Affect Questionnaire will form the basis of our follow-up study, it leads to several questions that are relevant for our present paper: How happy are the two cohorts of translators? Are they equally happy? If the translators are not equally happy, why not? What in fact makes them happy in their professional lives?

Given the paucity of the TS literature on translators' work-related happiness, internet websites offer some interesting survey results. According to an analysis carried out by the Guardian in 2015, engineers, teachers (!), and nurses are allegedly the happiest professions in the world. ${ }^{5}$ Intriguingly enough, there is no mention of translators. Similarly, in 2012, CareerBliss released its new list of the happiest jobs in the U.S., which included analysis from more than 100,400 employee-generated reviews, also failed to mention translators. ${ }^{6}$ These surveys suggest that in the present-day world translators do not rank among the happiest occupations. Still, the conundrum remains: how happy they are in reality.

\subsection{Translator as a profession}

According to Ruokonen (2013: 328), any of the concepts such as role and identity (Koskinen 2009; Setton and Guo Liangliang 2011), (self-)image (Sela-Sheffy 2010), self-concept (Ehrensberger-Dow and Massey 2013) or habitus (Sela-Sheffy and Shlesinger 2008) can be valid tools for studying the profession of translators including their status.

Although translators' status is often likened to that of secretaries (Dam and Zethsen 2008: 86-87; Katan 2009: 127) or teachers (Katan 2009: 127; Setton and Guo Liangliang 2011: 104-105) or is "below the poverty threshold" (Henter 2016: 38) in most European countries, it is doubtful if this comparison is applicable to legal translators, namely sworn and institutional translators who, along the translators' continuum, rank among the high-profile translators. This is due to their much higher 
level of remuneration in comparison to other types of translators at the national as well as supranational level. ${ }^{7}$ Aside from this, EU translators' international working environment is often associated even with a "glamorous lifestyle" (see Dam and Zethsen 2014: 97). Combining attribute and power approaches to distinguish professions from non-professions, Weiss-Gal and Welbourne (2008) list the following criteria as indicative of a profession: (1) public recognition of professional status, (2) professional monopoly over specific types of work, (3) professional autonomy of action, (4) possession of a distinctive knowledge base, (5) professional education regulated by the members of the profession, (6) an effective professional organization, (7) codified ethical standards, as well as (8) prestige and remuneration reflecting professional standing. Below, we shall have a look at how applicable these criteria are to our selected translators.

\subsubsection{Sworn translators in Slovakia}

Sworn translation in Slovakia represents a subfield of legal translation. Sworn translators are professional, certified translators entitled by the Ministry of Justice of the Slovak Republic in accordance with Act No. 382/2004 Coll. on Experts, Interpreters, and Translators ${ }^{8}$ (henceforth Act No. 383/2004) and its later amendments (DecreeLaws $490 / 2004^{9}$ and $491 / 2004,{ }^{10}$ as well Acts No. 522/2007 ${ }^{11}$ and No. 593/200712 on Experts, Translators, and Interpreters). They must be members of the official Registry of Experts, Interpreters, and Translators of the Slovak Republic. Each sworn translator must be a member of the list of JASPI. ${ }^{13}$ They perform translation activities for the court, other natural persons or legal entities. Slovak sworn translators are obliged to pass a professional exam ensured by the Ministry or an authorized expert institution to prove their knowledge in the legal field (constituting the so-called professional minimum) and in translation in order to practise. Although Müglová (2009: 71) sees deprofessionalization of the translation market in Slovakia as a serious problem, this cannot be applied to certified legal translation, which calls for quality translators guaranteed by the professional exam.

Although, after 1989, translation in Slovakia increased to the point that it could be a full-time occupation, it is doubtful whether it has evolved into a fully-fledged profession. Departing from Weiss-Gal and Welbourne's (2008) criteria, public recognition of professional status, prestige, and remuneration as a reflection of professional standing seem problematic. Notably, the public does not recognize the professional expertise needed to carry out legal translation to a desirable extent (although our research results in section 5.2.6 imply slightly otherwise). According to Godbout (2016), prestige is a result of economic and socio-cultural factors, stressing value to society. Although legal translation in Slovakia does have a value, which by its nature and financial facet is definitely better in comparison to other translation types (for example, the scandalously underpaid literary translation), overall remuneration is still not on a par with other academic professions. Thus, exhibiting the characteristics of a profession, but to a lesser degree, legal translation in Slovakia could be viewed as a semi-profession. Unlike institutional translators (see below), sworn translators as a focus group ${ }^{14}$ have never been studied with regard to social status parameters or variables of occupational prestige. 


\subsubsection{Institutional translators}

Institutional translation represents a specific sort of legal translation that takes place under highly specific circumstances within a multilingual language policy. To become a translator for the European Commission's Directorate General for Translation (DGT), the candidate has to be successful in an open competition that can last between five and nine months. Candidates must have knowledge of two foreign languages and a university degree, but not necessarily in languages. What is interesting is that the candidates do not require a degree or diploma in translation (Pym, Grin, et al. 2012: 12). ${ }^{15}$ The DGT, located in Luxembourg and Brussels, provides translation into the EU's twenty-four official languages; and with a total output of over 2,300,000 pages per year, it remains arguably the largest translation agency in the world (Bednárová-Gibová 2016: 53).

In contrast to sworn translators, EU translators seem to fulfil all eight Weiss-Gal and Welbourne's (2008) profession criteria. The single most important document that shapes EU translators' status is Staff Regulations; in it, however, translators are in no way differentiated. This speaks volumes about their position in the context of European multilingual language policy. EU translators themselves are also aware of their ambivalent role because, although they provide language services and work for other EU officials, sharing the same A-level status and salary levels, they see themselves as clearly detached from them (Koskinen 2009: 95).${ }^{16}$ Hence, their identification seems to be oriented more towards the professional group of translators rather than their institutional peers (Koskinen 2009: 96). In addition, they feel that they do not have a "substance value," which makes them psychologically subservient (Koskinen 2009: 95). As is well known, EU translators "seem to be suffering from translators' traditional lack of visibility in spite of their large numbers, central role and high pay" (Koskinen 2009: 99); so we shall look at how these variables have a bearing on their happiness at work.

\section{Research design}

In the study reported here, we set out to compare work-related happiness in two groups of legal translators-Slovak sworn and Slovak EU translators-in order to, one, determine the perceptions of happiness in their professional lives and, two, to characterize the differences between the two cohorts. To accomplish this aim, comparative and causal perspectives (see Ruokonen 2013) were employed. The comparative perspective, drawing on a quantitative analysis, rests on juxtaposing happiness perceptions in the two groups. The causal perspective analyzes correlations between happiness and various factors, such as social status variables and parameters of occupational prestige (Dam and Zethsen 2009, 2014). The quantitative analysis is comprised of a descriptive analysis and correlation analysis.

Social status variables such as age or gender and parameters of occupational prestige have already been studied in TS, however, not in relation to happiness conceived either theoretically or empirically. This is where the present investigation comes in. When deemed suitable, our research findings are compared to previous research on the selected parameters. 


\subsection{Goals and hypotheses}

In conjunction with a two-tiered thread in our research, the goals of the present study are as follows:

- to examine correlations between happiness, selected social status variables and parameters of occupational prestige between Slovak sworn translators and Slovak EU translators;

- to determine the greatest sources of satisfaction in their professional lives.

On the basis of the preliminary evaluation of the questionnaire (which is described in greater detail in section 4.2), along with the data subject to statistical processing, we devised the following seven hypotheses. Each hypothesis is backed up by its attendant motivator. All the hypotheses were tested with quantitative research methods employing contingency tables and the chi-square test $\left(\chi^{2}\right)$.

Hypothesis 1: Slovak EU translators are happier than Slovak sworn translators.

The study's central hypothesis draws on a fact that that EU translators have presumably a higher status in comparison to national legal translators, earn an excellent salary and are part of the stimulating working environment of the European Commission (see Koskinen 2008: 109, 111, 117), which could make them happier in theory.

Hypothesis 2: Younger translators are happier.

We predict that younger legal translators are happier than their older colleagues. This is also linked to the so-called "progressive disillusion" hypothesis (see Dam and Zethsen 2009: 30), which implies, for our research, that happiness decreases with age as individuals become aware of the pitfalls of the professional translator's life. Alternatively, the prediction could be reversed, especially with sworn translators, because older certified translators could have made a name for themselves among fierce competition in the national market and therefore they could have regular commissions. This could make their professional life stable and thus happy.

Hypothesis 3: Translators with higher remuneration are happier.

The hypothesis proceeds from a fact that salary is an important status parameter (Dam and Zethsen 2009: 14), a measure of success in our present-day money-driven society as well as a means of freedom and material contentment. Hence, it will be interesting to test whether a higher income gives EU translators professional satisfaction and if so, to what degree.

Hypothesis 4: Legal translation is a low-status occupation despite the relatively high remuneration.

This will be particularly interesting to test especially with EU translators as they are expected to earn a good living. Contrary to our general expectations about the translators' status, we state the opposite based on the previous research by Dam and Zethsen (2014). They found that, not only did EU translators not rate their occupational status higher than did national-market translators, but surprisingly their general status ratings were relatively low (below the middle value of 3). Although status is a complex, subjective, and context-dependent notion (Ollivier 2000: 456), we shall observe whether salary influences status perception and if so, how. 
Hypothesis 5: The more visible translators are, the happier they are.

We expect professional and physical visibility (see Dam and Zethsen 2014: 108109) to subconsciously influence the translator's happiness. We shall compare our research findings with previous research by Liu (2011).

Hypothesis 6: The more decision-making power and influence translators have, the happier they are.

Psychology dictates that authority and power make people happy (see Weiss-Gal and Welbourne 2008). Although power/influence is a profession trait which translators are often said to lack (see Venuti 1995; Snell-Hornby 2006; Dam and Zethsen 2014; Bednárová-Gibová 2016), it will be intriguing to test this assumption with legal translators who could feel differently owing to the nature of their translation, depending on the point of view they adopt.

Hypothesis 7: Greater happiness on the part of translators comes from their inwardoriented perspective rather than outside factors.

Here, drawing on Katan (2009: 149), we presume that translators will not look for their greatest professional satisfaction in fulfilling clients/end user expectations (thus not acting in compliance with functionalist skopos theory) or earning respect, but in the expertise and exquisite translation skills they gain.

\subsection{Data and methods}

To recruit translators to participate in this research, a non-probability convenience sampling method and snowball techniques were used. Quantitative statistical analyses were applied to the data to yield results.

The data were collected over a period of two months from May to June 2017 and are based on a total of 118 returned questionnaires. The jaspi.justice.gov.sk website provided the contact details for 172 Slovak sworn translators. Of these, 16 e-mails were returned automatically due to invalid e-mail addresses that had not been updated. Thus, based on a total of 156 potential responses and a total of 86 received responses, the response rate was 55\%. Slovak EU translators were contacted officially via the Head of the Slovak translation unit in Luxembourg who agreed to send them a link to our e-questionnaire. Out of 53 available Slovak EU translators, and based on a total of 32 responses, the response rate was as high as $60 \%$. In sum, we sent three calls for completing our e-questionnaire to increase interest in participating in our research. As regards sworn translators, some were also contacted on their mobile phones, which helped to increase their eagerness to participate.

The respondents' selection criteria, which were based on legal translation practice, Slovak nationality, a minimum of 5 years of work experience and fully completed questionnaires (with the exception of a sensitive question about one's income), served to ensure a sample of translators with the required profile. Closer scrutiny of the questionnaires, however, revealed 3 respondents who did not match the inclusion criteria and had to be excluded from the sample. The final sample thus consisted of data from a total of 83 sworn translators and 32 EU translators, that is to say 115 completed questionnaires that met our criteria. 
The questionnaire was created on the click4survey.sk website ${ }^{17}$ and consisted of 31 questions, of which 25 were semi-closed, 4 closed and 2 open. Of the semi-closed questions, 5 were item list questions, 19 Likert scale questions and 1 question grid. The questionnaire was used as a means to identify variables and formulate research hypotheses. In determining the questions for the survey, we consulted secondary sources, psychologists, and statisticians. Some semi-closed questions use a traditional 5 -point Likert scale although others use an eleven-point end defined scale (where 0 $=$ very dissatisfied, $10=$ very satisfied) to measure an individual's happiness (see for example Cummins and Gullone 2000). However, if informants were provided with too many options, such as 'pretty much agree' or 'sort of agree,' it would be much more complicated (if possible at all) to evaluate the degree of their agreement/disagreement. As this problem is avoided in the 5-point Likert scale, we decided to use it in the present research. The questionnaire data were used to evaluate the following categories:

a) Translator's profile: age, gender, education level, extent of translation activities, amount of time dedicated to translation;

b) Status and selected parameters of occupational prestige: remuneration, visibility, power/influence, and appreciation;

c) The sources of the greatest professional satisfaction.

Several direct and indirect questions were asked in relation to each category. To ensure the credibility of our data, we compared the interpretation of our results with those from Dam and Zethsen (2009, 2011, 2014), Katan (2009, 2011), and Liu (2011), with a view to selected research parameters. To corroborate or refute the hypotheses, statistical tests determining the $\chi^{2}$ and $p$-values were used.

\section{Analyses and results}

This section of the paper is devoted to presenting and interpreting the results of the survey. We shall consider the results of the analysis in relation to each of the parameters that formed the focus of the research.

\subsection{Descriptive analysis: the translator's profile}

Based on the gained results, we compared the translator's basic profile for the two cohorts, drawing attention to the most intriguing findings. Age of the informants will be discussed in correlation with happiness in section 5.2.

As concerns gender, the proportion of women to men in the Slovak sworn translators sample is $65.06 \%$ to $34.94 \%$. Similarly, it is $68.75 \%$ women and $31.25 \%$ men in the Slovak EU sample. These findings confirm that even legal translation is evidently a female occupation. This may be a tad surprising given the nature of the translated documents. Our findings are, however, consonant with those by Dam and Zethsen (2009); Katan (2009, 2011); Pym, Grin, et al. (2012); Djovčoš (2014), Solová (2015), Djovčoš and Šveda (2017) despite differences in geographical location, time, and translator types. Twice as many female sworn translators as males gave positive answers when assessing their work-related happiness (45\% of them are 'very happy' or 'happy' in comparison to $23 \%$ of men), and the situation is also very similar with EU translators (in the ratio $40.6 \%$ to $18.75 \%$ ). This gender difference shows that, especially 
from a feminist TS angle, the issue of gender and translators' happiness certainly merits further investigation in the future.

With respect to education, $77.10 \%$ of sworn translators hold an M.A. degree (with a high prevalence in the humanities followed by specialization in law and technical engineering) and $14.45 \%$ a $\mathrm{PhD}$ degree, compared to $87.5 \%$ and $12.5 \%$ among $\mathrm{EU}$ translators. A vital difference between the two groups concerns the holders of a postdoctoral degree, which is present in only $6 \%$ of sworn translators. These are mostly academics working part-time as sworn translators alongside their main occupation. Such a subgroup is conspicuously absent in the EU sample, which could imply that extra academic education is not necessary for performing quality legal translation in EU institutions. Interestingly, a vast majority of all translators in the sample (84.38\% of sworn and $87.95 \%$ of EU translators) rate the degree of expertise required to perform their job as 'high' or 'very high.' This finding is in agreement with Dam and Zethsen (2011) whose company, agency, and freelance translators all gave average expertise scores of 4 on a 1-5 rating scale. However, external recognition also shapes a profession's status. Our data show that, according to the translators' opinions, people outside the translation profession hold legal translators' expertise mostly in 'high' or 'certain' esteem. This finding differs (in a positive sense) from the abovementioned research by Dam and Zethsen (2011). The reason could possibly be sought in the nature of legal translation, a profession that imposes natural respect and esteem, especially with regard to EU translators.

As regards the amount of time dedicated to translation, almost a half of the EU translators working 31-40 hours (44.87\%) or >40 hours per week (53.13\%) are either 'very happy' or 'happy.' Sworn translators, on the contrary, dedicate much less time to translation. $28.91 \%$ of 'very happy' or 'happy' sworn translators work $<10$ hours or 11-20 hours per week. Then there are $13.25 \%$ who work $21-30$ hours and $31.32 \%$ dedicate either $31-40$ or $>40$ hours to translation per week, and who rate themselves as 'happy/very happy' professionals. The varying hour ranges in the sworn translators group also depend on whether they work full-time (55.42\%) or part-time (44.57\%). The part-time possibility for sworn translation in Slovakia is a salient feature distinguishing them from EU translators, who work 100\% full-time. For sworn translators, happiness does not directly correlate with longer hours dedicated to translation.

In the subsequent section we will put our hypotheses to the test and interpret them.

\subsection{Correlation analysis}

\subsubsection{Age}

We divided all the respondents in the analyzed sample into five age groups (see Tables 1 and 2). As Table 1 shows, there are no translators in the 25-29 age range among the Slovak sworn translators. The absence of young translators can be explained by Act No. 382/2004 and its later amendments (see section 3.2.1), which imposes a compulsory 5-year practice in the field prior to taking the official exam. Work-related happiness is most reflected in the 30-39 age group, in which $37.35 \%$ of the respondents perceive themselves as either 'very happy' or 'happy' and $8.43 \%$ rank themselves as 'neither happy nor unhappy.' A comparable level of happiness is present in the 40-49 age group despite a lower number of translators. A considerable decrease in happiness is, however, manifest in the 50-59 age group, in which fewer 
than $5 \%$ see themselves as 'very happy' or 'happy.' Interestingly enough, the senior group, over 60 years old, revealed a noticeable increase in happiness again, which could lend certain evidence to our hypothesis 2 motivator in relation to older certified translators.

TABLE 1

Correlation between happiness and age: sworn translators

\begin{tabular}{|l|c|c|c|c|c|}
\hline Age Range & $\mathbf{2 5 - 2 9}$ & $\mathbf{3 0 - 3 9}$ & $\mathbf{4 0 - 4 9}$ & $\mathbf{5 0 - 5 9}$ & $>\mathbf{6 0}$ \\
\hline Very happy & 0 & 9 & 4 & 1 & 2 \\
\hline Happy & 0 & 22 & 10 & 3 & 5 \\
\hline Neither happy nor unhappy & 0 & 7 & 8 & 3 & 6 \\
\hline Unhappy & 0 & 0 & 1 & 1 & 0 \\
\hline Very unhappy & 0 & 1 & 0 & 0 & 0 \\
\hline
\end{tabular}

$\chi^{2}=15.368$

As for EU translators, the greatest work-related happiness is similarly observable in the 30-39 and 40-49 age groups (25\% being 'very happy' or 'happy' in both groups), and there is also a decrease in the 50-59 age group, in which as few as $3 \%$ view themselves 'happy.' In marked contrast to sworn translators, there are no active translators in the senior group (see Table 2). This could imply that translating for EU institutions is not a lifetime job because of the nature of translation. This was confirmed by an anonymous respondent: "It is the monotony of the job that beats me down and the gap between one's knowledge and what you are expected to know (expertise in various domains), without providing the appropriate time for research and the context for the legislation we translate. I don't think this will be my job until I retire."

TABLE 2

Correlation between happiness and age: EU translators

\begin{tabular}{|l|c|c|c|c|c|}
\hline Age Range & $\mathbf{2 5 - 2 9}$ & $\mathbf{3 0 - 3 9}$ & $\mathbf{4 0 - 4 9}$ & $\mathbf{5 0 - 5 9}$ & $>\mathbf{6 0}$ \\
\hline Very happy & 1 & 2 & 2 & 0 & 0 \\
\hline Happy & 1 & 6 & 6 & 1 & 0 \\
\hline Neither happy nor unhappy & 0 & 6 & 2 & 1 & 0 \\
\hline Unhappy & 0 & 1 & 3 & 0 & 0 \\
\hline Very unhappy & 0 & 0 & 0 & 0 & 0 \\
\hline
\end{tabular}

$\chi^{2}=6.454$

Overall, based on Tables 1 and 2, it may be claimed that the translators in the 30-39 and 40-49 age groups seem happier in comparison to the 50-59 and >60 age groups. However, hypothesis 2 was not confirmed for either of the two groups, as the $\chi^{2}$ test values are 15.368 and 6.454 , respectively. In both groups the p-value is $>0.05$, which means that the correlation between happiness and age is not statistically significant. In other words, we did not find a direct correlation between happiness and age. 


\subsubsection{Status}

In the questionnaire the respondents were asked how they perceive their status as translators.

TABLE 3

Correlation between happiness and status: sworn translators

\begin{tabular}{|l|c|c|c|c|c|}
\hline Status & Very High & High & Average & Low & Very Low \\
\hline Very happy & 2 & 8 & 6 & 0 & 0 \\
\hline Happy & 0 & 23 & 12 & 5 & 0 \\
\hline Neither happy nor unhappy & 0 & 4 & 15 & 5 & 0 \\
\hline Unhappy & 0 & 0 & 0 & 2 & 0 \\
\hline Very unhappy & 0 & 0 & 0 & 0 & 1 \\
\hline
\end{tabular}

$\chi^{2}=116.458$

The data in Table 3 show that $44.58 \%$ of sworn translators rate their status as 'very high' or 'high,' $39.76 \%$ as 'average' and only $15.66 \%$ as 'low.' If we were to convert the response categories into numerical values between 1 and 5 ( $1=$ very low, $5=$ very high), their mean status ranking would be 3.3 , that is to say average. In contrast, EU translators view their status, perhaps surprisingly, as lower; 37.5\% of them hold the view that their status is either 'low' or 'very low' (see Table 4). Expressed in numerical values, their mean status rating is slightly lower, at 2.96, or below average. Although the difference is not large, it is statistically significant.

TABLE 4

Correlation between happiness and status: EU translators

\begin{tabular}{|l|c|c|c|c|c|}
\hline Status & Very High & High & Average & Low & Very Low \\
\hline Very happy & 3 & 2 & 0 & 0 & 0 \\
\hline Happy & 1 & 4 & 6 & 3 & 0 \\
\hline Neither happy nor unhappy & 0 & 0 & 2 & 4 & 3 \\
\hline Unhappy & 0 & 1 & 1 & 1 & 1 \\
\hline Very unhappy & 0 & 0 & 0 & 0 & 0 \\
\hline
\end{tabular}

$\chi^{2}=25.290$

These outcomes suggest that even among these supposedly high-profile translators, legal translation is not connected with a high status, regardless of whether the translators are employed in a national market or an international setting. Our results are also identical to those of Dam and Zethsen (2011: 984, 2014: 102) and Katan's survey (2009: 126), in which translators have at best a middling status. In sum, based on the data in Tables 3 and 4, it can be argued that there is a direct correlation between happiness and status for sworn translators $\left(\chi^{2}=116.458\right.$, which is significant at $\mathrm{p}$-level $<0.01)$ as well as for EU translators $\left(\chi^{2}=25.290\right.$ at $\mathrm{p}$-level $\left.<0.05\right)$

An analysis of the correlation between status and salary satisfaction (see Tables 5 and 6) reveals the following: there is a clear correlation between salary satisfaction 
and lower status perceptions (lower salary satisfaction correlates with lower status ratings, and high salary correlates with an absence of lower status ratings) for sworn translators $\left(\chi^{2}=109.775\right.$ at $\mathrm{p}$-level $\left.<0.01\right)$. On the other hand, there is no correlation between salary satisfaction and high-status ratings for EU translators $\left(\chi^{2}=4.571\right)$. One of the reasons could lie in a sample size that may not be sufficient to make a stronger affirmation. Hypothesis 4 was not confirmed as with regard to sworn translators, but it was borne out for EU translators.

TABLE 5

Correlation between status and salary satisfaction: sworn translators

\begin{tabular}{|l|c|c|c|c|c|}
\hline Status & Very High & High & Average & Low & Very Low \\
\hline Salary satisfaction & & & & & \\
\hline Very satisfied & 0 & 4 & 1 & 0 & 0 \\
\hline Satisfied & 2 & 23 & 10 & 3 & 0 \\
\hline Average & 0 & 7 & 19 & 5 & 0 \\
\hline Dissatisfied & 0 & 1 & 2 & 4 & 0 \\
\hline Extremely dissatisfied & 0 & 0 & 0 & 0 & 1 \\
\hline
\end{tabular}

$\chi^{2}=109.775$

TABLE 6

Correlation between status and salary satisfaction: EU translators

\begin{tabular}{|l|c|c|c|c|c|}
\hline Status & Very High & High & Average & Low & Very Low \\
\hline Salary satisfaction & & & & & \\
\hline Very satisfied & 3 & 6 & 9 & 8 & 4 \\
\hline Satisfied & 1 & 1 & 0 & 0 & 0 \\
\hline Average & 0 & 0 & 0 & 0 & 0 \\
\hline Dissatisfied & 0 & 0 & 0 & 0 & 0 \\
\hline Extremely dissatisfied & 0 & 0 & 0 & 0 & 0 \\
\hline
\end{tabular}

$\chi^{2}=4.571$

\subsubsection{Remuneration}

Salary is widely believed to be a chief determinant of occupational prestige (see Weisgal and Welbourne 2008, among others). As indicated in Table 6, high remuneration per se may not be sufficient to ensure a high-status perception of the translation profession. Despite salary being potentially a good indicator of status, it may not play the decisive role in translators' happiness.

In this study we asked the translators to state their level of satisfaction with their salary and we asked them to mark their monthly income ranges. The results are displayed in Tables 7-10 respectively. 
TABLE 7

Correlation between happiness and salary: sworn translators

\begin{tabular}{|l|c|c|c|c|c|}
\hline Satisfaction with Salary & $\begin{array}{c}\text { Very } \\
\text { Satisfied }\end{array}$ & Satisfied & Average & Dissatisfied & $\begin{array}{c}\text { Extremely } \\
\text { Dissatisfied }\end{array}$ \\
\hline Very happy & 2 & 7 & 5 & 1 & 0 \\
\hline Happy & 3 & 23 & 13 & 1 & 0 \\
\hline Neither happy nor unhappy & 0 & 8 & 12 & 4 & 0 \\
\hline Unhappy & 0 & 0 & 1 & 1 & 0 \\
\hline Very unhappy & 0 & 0 & 0 & 0 & 1 \\
\hline
\end{tabular}

$\chi^{2}=94.778$

TABLE 8

Correlation between happiness and salary: EU translators

\begin{tabular}{|l|c|c|c|c|c|}
\hline Satisfaction with Salary & $\begin{array}{c}\text { Very } \\
\text { Satisfied }\end{array}$ & Satisfied & Average & Dissatisfied & $\begin{array}{c}\text { Extremely } \\
\text { Dissatisfied }\end{array}$ \\
\hline Very happy & 4 & 1 & 0 & 0 & 0 \\
\hline Happy & 13 & 1 & 0 & 0 & 0 \\
\hline Neither happy nor unhappy & 9 & 0 & 0 & 0 & 0 \\
\hline Unhappy & 4 & 0 & 0 & 0 & 0 \\
\hline Very unhappy & 0 & 0 & 0 & 0 & 0 \\
\hline
\end{tabular}

$\chi^{2}=2.499$

As we can see in Tables 7 and 8, for sworn translators there is a much more varied level of satisfaction with their salaries compared to EU translators; $93.75 \%$ of them are 'very satisfied.' This result could reflect the correlation between the level of satisfaction with salary and happiness in this group. Moreover, this study has revealed large salary differences between the two groups. As has been emphasized in the literature and translation practice time and again, EU translators count high income levels, which has also been unequivocally confirmed in our study: $75 \%$ of them earn $>5,000$ EUR per month and 25\% adduce between 3,000 and 5,000 EUR (see Table 10). The Slovak sworn translators' salaries are significantly lower, as documented by Table 9. It is interesting to note, though, that despite this huge salary gap in comparison to EU translators, $64.47 \%$ of sworn translators state that they are either 'very happy' or 'happy' with their profession. At the same time, more than a half of them said they earned less than 1,000 EUR or between 1,000 and 2,000 EUR, which is below the average monthly income or even below the poverty threshold in many European countries (see Henter 2016: 38). However, despite these weak earnings for Slovak certified translation, they still feel professionally satisfied. What also deserves mention is that as many as $92 \%$ of the Slovak sworn translators indicated their monthly income. For the rest, this seemed a very sensitive question; they refused to indicate their monthly income range. This implies that stating their remuneration means stepping outside their comfort zone in marked contrast to EU translators. 
TABLE 9

Correlation between happiness and the level of remuneration in EUR: sworn translators

\begin{tabular}{|l|c|c|c|c|c|}
\hline Salary in EUR & $\begin{array}{c}\mathbf{> 5 , 0 0 0} \\
\text { EUR }\end{array}$ & $\begin{array}{c}\mathbf{3 , 0 0 0 - 5 , 0 0 0} \\
\text { EUR }\end{array}$ & $\begin{array}{c}\mathbf{2 , 0 0 0 - 3 , 0 0 0} \\
\text { EUR }\end{array}$ & $\begin{array}{c}\mathbf{1 , 0 0 0 - 2 , 0 0 0} \\
\text { EUR }\end{array}$ & $\begin{array}{c}<\mathbf{1 , 0 0 0} \\
\text { EUR }\end{array}$ \\
\hline Very happy & 0 & 0 & 5 & 6 & 4 \\
\hline Happy & 1 & 0 & 5 & 13 & 15 \\
\hline Neither happy nor unhappy & 0 & 0 & 5 & 6 & 13 \\
\hline Unhappy & 0 & 0 & 1 & 0 & 1 \\
\hline Very unhappy & 0 & 0 & 0 & 0 & 1 \\
\hline
\end{tabular}

$\chi^{2}=8.204$

TABLE 10

Correlation between happiness and the level of remuneration in EUR: EU translators

\begin{tabular}{|l|c|c|c|c|c|}
\hline Salary in EUR & $\begin{array}{c}\mathbf{5}, \mathbf{0 0 0} \\
\text { EUR }\end{array}$ & $\begin{array}{c}\mathbf{3 , 0 0 0 - 5 , 0 0 0} \\
\text { EUR }\end{array}$ & $\begin{array}{c}\mathbf{2 , 0 0 0 - 3 , 0 0 0} \\
\text { EUR }\end{array}$ & $\begin{array}{c}\mathbf{1 , 0 0 0 - 2 , 0 0 0} \\
\text { EUR }\end{array}$ & $\begin{array}{c}<\mathbf{1 , 0 0 0} \\
\text { EUR }\end{array}$ \\
\hline Very happy & 4 & 1 & 0 & 0 & 0 \\
\hline Happy & 11 & 3 & 0 & 0 & 0 \\
\hline Neither happy nor unhappy & 6 & 3 & 0 & 0 & 0 \\
\hline Unhappy & 3 & 1 & 0 & 0 & 0 \\
\hline Very unhappy & 0 & 0 & 0 & 0 & 0 \\
\hline
\end{tabular}

$\chi^{2}=0.495$

Based on Tables 9-10, there are non-significant correlations between happiness and the level of remuneration for both groups. The correlations between the two variables were not confirmed for any of the groups $\left(\chi^{2}=8.204\right.$ and $\chi^{2}=0.495$, respectively). Despite the statistical results, however, at first sight the data in the tables imply that EU translators are happy with their higher level of remuneration while sworn translators are happy with their lower remuneration. Statistically speaking, however, hypothesis 3 must be rejected.

\subsubsection{Visibility}

Although the visibility of a profession is a commonly acknowledged status parameter, in TS the concept has had its own meaning since Venuti's times. Translators are often portrayed in the secondary sources as "physically and professionally isolated" (Dam and Zethsen 2009: 21). In this study we used different phrasing of the visibility issue in relation to these two aspects.

Physical visibility is closely connected with the location of one's workplace, whether one is located in a central or peripheral position in the organization or whether one is "hard to identify" as translators work mostly from home. A crucial between-group difference is that, while $68.29 \%$ of sworn translators work mostly from home and could thus be characterized by true physical isolation, this is hardly the case for EU translators (except for special permission after a certain period of employment). Although EU translators usually sit alone in their offices, 56.25\% of them perceive their physical location as 'neither central nor peripheral.' There is no relationship between happiness and physical visibility in either group. 
As for professional visibility, we asked the translators to rate the degree of their professional contact with others (colleagues, employees, clients, etc.). Remarkably, the between-group comparison yielded an identical result-both sworn and EU translators rated their degree of contact as 'average,' in other words, the mean values of the contact ratings were 3.2 (on the 1-5 scale after numerical conversion of the data); so professional isolation is not an issue for either group. We also found a direct relationship between happiness and the degree of contact. This points to the importance of professional contact over physical location when assessing the translators' work-related happiness.

These relatively high contact ratings in sworn translators may seem to contradict their low physical visibility discussed above. However, we assume that they mostly have contact with clients or end users for whom they translate. The relatively high professional contact for EU translators may also contradict their complaints about the lack of feedback from clients (Dam and Zethsen 2014: 110), but we surmise that their contacts are mostly directed towards in-house colleagues rather than towards any other group. Still, EU translators suffer from a significantly lower degree of name visibility in comparison to sworn translators: $81.25 \%$ of EU translators never reveal their names in their translations as opposed to only $3.61 \%$ of sworn translators. As the between-group comparison shows, based on the data in Tables 11 and 12, there is a clearly confirmed significant correlation between happiness and visibility for sworn translators $\left(\chi^{2}=29.528\right.$ at p-level $\left.<0.05\right)$ in contrast to EU translators $\left(\chi^{2}=\right.$ 10.919). Thus, hypothesis 5 is corroborated, but only for sworn translators and not for EU translators. Our finding that the client-visible sworn translators seem happier than the behind-the-scene EU translators is also in agreement with Liu (2011).

TABLE 11

Correlation between happiness and name visibility: sworn translators

\begin{tabular}{|l|c|c|c|c|c|}
\hline Name Visibility & Very Often & Often & Sometimes & Seldom & Never \\
\hline Very happy & 9 & 5 & 1 & 1 & 0 \\
\hline Happy & 18 & 9 & 5 & 5 & 3 \\
\hline Neither happy nor unhappy & 10 & 10 & 2 & 2 & 0 \\
\hline Unhappy & 1 & 0 & 1 & 0 & 0 \\
\hline Very unhappy & 0 & 0 & 0 & 0 & 1 \\
\hline
\end{tabular}

$\chi^{2}=29.528$

TABLE 12

Correlation between happiness and name visibility: EU translators

\begin{tabular}{|l|c|c|c|c|c|}
\hline Name Visibility & Very Often & Often & Sometimes & Seldom & Never \\
\hline Very happy & 0 & 0 & 1 & 0 & 4 \\
\hline Happy & 1 & 0 & 0 & 3 & 10 \\
\hline Neither happy nor unhappy & 0 & 0 & 0 & 0 & 9 \\
\hline Unhappy & 0 & 0 & 1 & 0 & 3 \\
\hline Very unhappy & 0 & 0 & 0 & 0 & 0 \\
\hline
\end{tabular}

$\chi^{2}=10.919$ 


\subsubsection{Power/influence}

As much as power or influence is known to be conspicuously absent in the translation profession, we shall nevertheless look at the legal translators' assessments. These could potentially differ on the strength of the perception of their legal responsibilities towards a text and its end user. Numerical conversion of the data in Tables 13 and 14 reveals that sworn translators' mean power scores reach the value of 3.02 on the 1-5 rating scale, that is to say an 'average' influence. EU translators assess their power even lower at 2.12, that is, at a 'low influence.' This supports the fact that institutional translators are well aware of the manipulating forces behind the EU machinery and realize their role as inert participants in a communication act: they cannot enforce their own alternative translation variants and contribute to a text's meaning-making, which could be interpreted as a manifestation of institutional restraint on their decision-making power (see Bednárová-Gibová 2016: 82 for more). Sworn translators, on the other hand, feel that they have greater power over their translations, although they do acknowledge some constraints.

As can be derived from Tables 13 and 14, there is clearly a significant correlation between happiness and power for sworn translators $\left(\chi^{2}=35.061\right.$ at $\mathrm{p}$-level $\left.<0.01\right)$, but not for EU translators $\left(\chi^{2}=15.681\right)$. Again, hypothesis 6 is confirmed only for sworn translators, but not for EU translators.

TABLE 13

Correlation between happiness and power: sworn translators

\begin{tabular}{|l|c|c|c|c|c|}
\hline Power & Very High & High & Average & Low & Very low \\
\hline Very happy & 0 & 5 & 9 & 1 & 1 \\
\hline Happy & 2 & 15 & 16 & 7 & 0 \\
\hline Neither happy nor unhappy & 0 & 4 & 11 & 6 & 3 \\
\hline Unhappy & 0 & 0 & 0 & 2 & 0 \\
\hline Very unhappy & 0 & 0 & 0 & 0 & 1 \\
\hline
\end{tabular}

$\chi^{2}=35.061$

TABLE 14

Correlation between happiness and power: EU translators

\begin{tabular}{|l|c|c|c|c|c|}
\hline Power & Very High & High & Average & Low & Very low \\
\hline Very happy & 1 & 1 & 2 & 0 & 1 \\
\hline Happy & 1 & 0 & 4 & 6 & 3 \\
\hline Neither happy nor unhappy & 0 & 0 & 1 & 4 & 4 \\
\hline Unhappy & 0 & 0 & 0 & 1 & 3 \\
\hline Very unhappy & 0 & 0 & 0 & 0 & 0 \\
\hline
\end{tabular}

$\chi^{2}=15.681$

Another intriguing finding is that while power is a rather soft parameter for the translators, the related psychological concept of responsibility, based on one's internal obligations, seems much more important to them. Both groups assign 'a very 
high' or 'high' degree of responsibility to their jobs in over $90 \%$ of the responses, which attests to the seriousness of legal translation.

\subsubsection{Appreciation}

Similarly to responsibility, appreciation is not given as a status parameter in the literature on occupational prestige. On the other hand, those who come closest to investigating translator status often speak of a "lack of societal recognition" (Katan 2009: 125), a "semi-profession" (Godbout 2016) or "a transitory occupation" (Dam and Zethsen 2016: 177).

Judging by the data in Tables 15 and 16, both groups feel that their work is appreciated although a fair number of the translators are not overly optimistic. The appreciation score ratings in both groups are remarkably similar, with mean values of 3.38 (EU translators) and 3.44 (sworn translators), which corresponds to 'a certain extent.' These findings are partly in line with the previous research by Dam and Zethsen (2009: 29), however, they extend its validity for a particular translator microhabitus. As shown in Tables 15 and 16, a direct correlation between happiness and appreciation exists in the sample of sworn translators $\left(\chi^{2}=22.794\right.$ at the significance level $\mathrm{p}<0.05)$ : the more appreciated the translators feel, the happier they are. On the other hand, there is no correlation between happiness and appreciation for EU translators $\left(\chi^{2}=15.281\right)$. However, this finding could be related to their limited sample size.

TABLE 15

Correlation between happiness and appreciation: sworn translators

\begin{tabular}{|l|c|c|c|c|c|}
\hline Appreciation & Very High & High & Certain & Low & Very low \\
\hline Very happy & 1 & 7 & 7 & 1 & 0 \\
\hline Happy & 4 & 21 & 14 & 1 & 0 \\
\hline Neither happy nor unhappy & 2 & 7 & 12 & 3 & 0 \\
\hline Unhappy & 0 & 0 & 2 & 0 & 0 \\
\hline Very unhappy & 0 & 0 & 0 & 1 & 0 \\
\hline
\end{tabular}

$\chi^{2}=22.794$

TABLE 16

Correlation between happiness and appreciation: EU translators

\begin{tabular}{|l|c|c|c|c|c|}
\hline Appreciation & Very High & High & Certain & Low & Very low \\
\hline Very happy & 1 & 2 & 2 & 0 & 0 \\
\hline Happy & 0 & 9 & 4 & 1 & 0 \\
\hline Neither happy nor unhappy & 0 & 3 & 5 & 1 & 0 \\
\hline Unhappy & 0 & 0 & 2 & 2 & 0 \\
\hline Very unhappy & 0 & 0 & 0 & 0 & 0 \\
\hline
\end{tabular}

$\chi^{2}=15.281$ 


\subsubsection{The sources of the greatest happiness and overall summary}

In our questionnaire, the translators were also asked to mark what imbues them with the greatest satisfaction in their professional life on a 1-5 rating scale where 1 stands for 'strongly agree' and 5 for 'strongly disagree.' The results of the between-group comparison are displayed in Figures $1 \mathrm{a}$ and $1 \mathrm{~b}$.

FIGURE 1a

Comparison of the sources of the greatest professional satisfaction (absolute frequencies): sworn translators

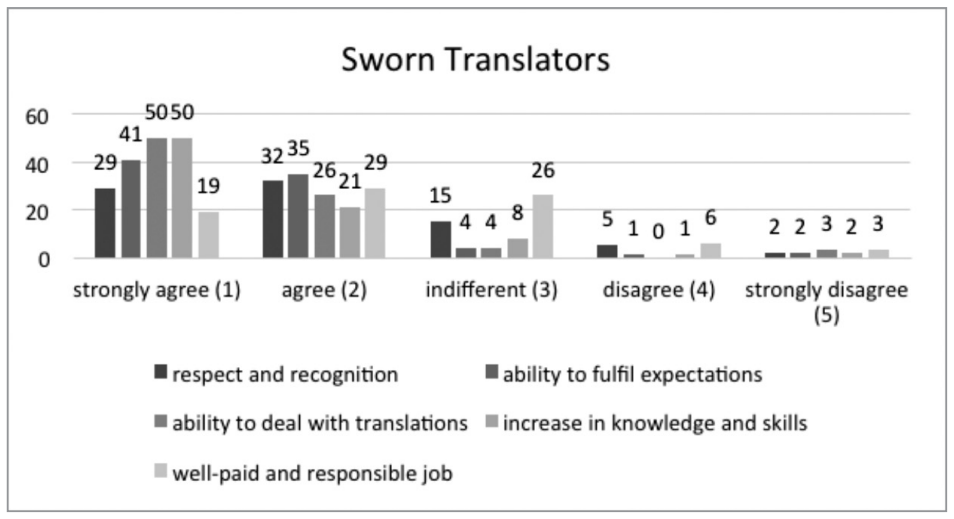

FIGURE $1 \mathrm{~b}$

Comparison of the sources of the greatest professional satisfaction (absolute frequencies): EU translators

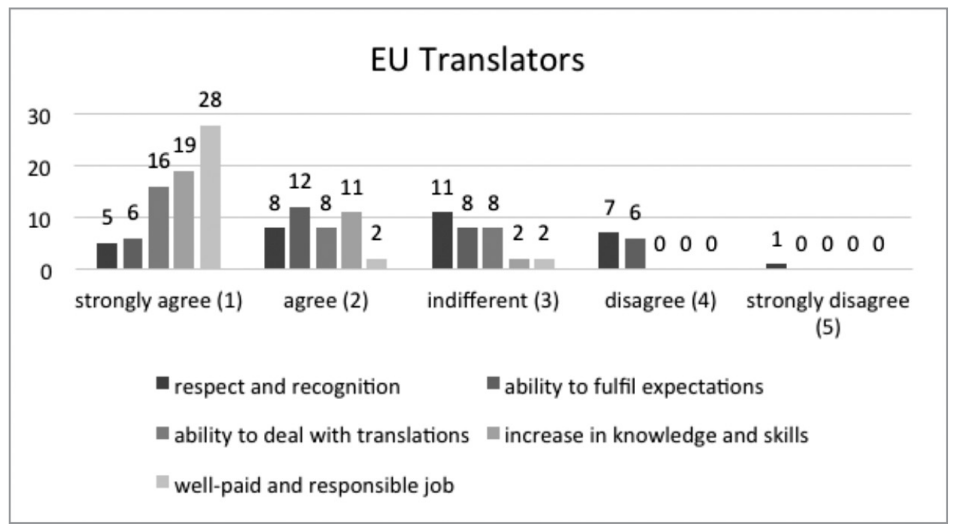

As can be inferred from Figures 1a and 1b, both groups acknowledge that their abilities to deal with difficult translations and the increase in knowledge and translation skills that come with their work give them the greatest sources of professional satisfaction. This testifies to their inward-looking personality traits and self-focused working attitude. Although outer factors, such as respect and recognition or ability to fulfil the expectations of clients/end-users, play a more vital role for sworn translators than for EU translators, they seem much less important to both groups. Thus, it can be claimed that hypothesis 7 has been corroborated. However, salary as a 
traditional hard-core status parameter cannot be underestimated for EU translators, who clearly recognize it as the greatest source of satisfaction at work. On the other hand, for sworn translators, money seems to play a far less significant role, which is caused by a much lower remuneration that compels them to look for professional satisfaction elsewhere.

Finally, our study's central hypothesis has not been borne out as sworn and EU translators seem equally happy with their profession; their mean happiness rating scores are 3.86 and 3.75, respectively, which is not statistically significant. Moreover, in the EU sample, there is a larger number of unhappy translators (12.5\%). The final comparison, based on absolute frequencies, is displayed in Figure 2.

\section{FIGURE 2}

Comparison of translators' work-related happiness (absolute frequencies)

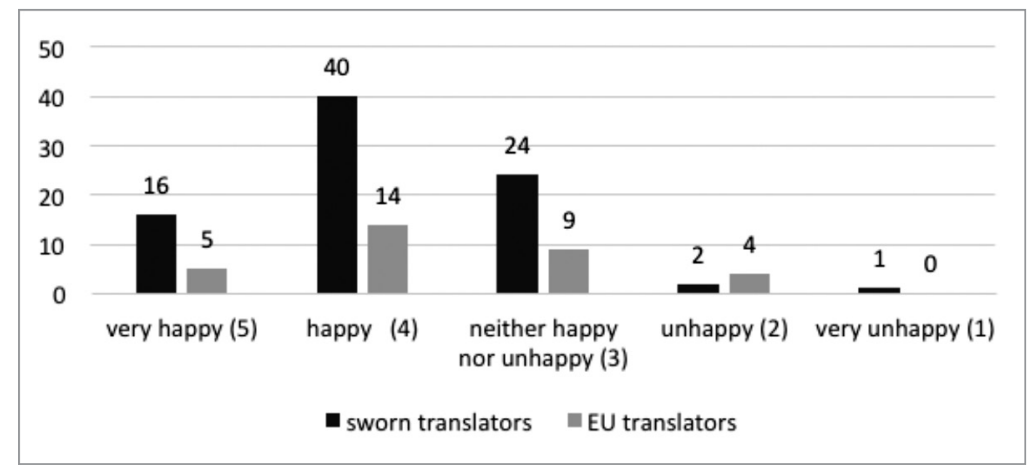

As this study draws to a close, we invite you to read the following commentary from an EU translator from our sample which, we believe, accurately illustrates their situation: "I have many colleagues who are unhappy with their jobs in the Commission, mostly because they are trained in other areas of translation (law, engineering, international relations), so presumably they hoped for a more exciting career path. However, they mainly stay for the salary that is exceptionally high." Another quote from an anonymous sworn translator says it all: "When you are a sworn translator, it is really hard to say whether the job makes you happy or not. It is a very professional job that requires much expertise and seriousness. However, I can definitely say that I am a useful person and my translations have helped many people. And THAT ${ }^{18}$ makes me satisfied."

\section{Conclusion}

To sum up, a variety of different parameters have been explored in this study, which allows for a series of generalizations, each of which contributes to casting some light on the issue of translators' happiness. Based on our research, it cannot be claimed that either one or the other of the translator groups is professionally happier than the other; both rated their work-related happiness closer towards the value of being 'happy.' We offered comparative insight into the translators' perceptions of happiness in their professional lives with a view to highlighting the differences between them. In line with the study's goals, we ascertained that while there are statistically non- 
significant correlations between happiness and age, and happiness and remuneration, there is a significant correlation between happiness and status in both groups. Correlations between happiness and occupational parameters such as visibility, power/influence, and appreciation are significant for sworn translators, but not for EU translators. Unlike sworn translators, in this group these occupational parameters do not correlate with work-related happiness.

Both cohorts of these high-profile translators seek professional satisfaction in inward-oriented job aspects (such as their abilities to deal with demanding translations and increase in knowledge resulting from translating) rather than in earning respect and recognition or fulfilling clients' expectations. This is a robust finding in connection with the translators' identity. In contrast to sworn translators, a high income is not regarded by EU translators as a weak occupational parameter when assessing their work-related happiness. We also found that for both groups legal translation is not perceived as a high-status occupation, despite its supposedly high profile. EU translators' mean status rankings were even lower than those of sworn translators. Professional contact and job responsibility enjoy the status of fairly strong parameters for both cohorts of translators: professional contact and responsibility seem more important than physical isolation and power/influence.

This research is the beginning of our longer longitudinal study; an investigation of translators' happiness, based on Veenhoven's concept will form the focus of the next study in our ongoing research. In the future, it will be enticing to explore the relationship between work-related happiness and a translator's personality in greater detail. The present study is a springboard for such further analyses, as it offers stimuli for comparison with other translator micro-habitus for which analyses have yet to be performed.

Last, but far from least, we are fully aware that our translational-sociological research may elicit controversies. Yet, we believe that, if we really regard translators as human beings, we should know more about their views and attitudes, including such subjective concepts as work-related happiness. Besides, we also believe that our longitudinal study of translators' happiness will enable us to arrive at a deeper understanding of this complicated profession.

\section{ACKNOWLEDGEMENTS}

The publication of this paper has been supported by the KEGA 036PU-4/2017 research grant. The collective data processing software used for statistical purposes was designed in collaboration with the Department of Computers and Informatics of the Faculty of Electrical Engineering and Informatics at the Technical University in Košice, Slovakia.

\section{NOTES}

1. Rubin, Theodore Isaac (1976): Love me, love my fool: thoughts from a psychoanalyst's notebook. New York: McKay.

2. NefF, Jacquy (14 March 2011): A Statistical Portrait of AIIC: 2005-2009. aiic.net. Consulted 4 April 2017, <http://aiic.net/p/3585>.

3. According to Tryuk's research results on job satisfaction among community interpreters in Poland, almost $90 \%$ of the respondents were satisfied with their professions; this underscored that "job satisfaction was closely related to the whole atmosphere, the quality of interpersonal contacts, the intellectual rapport and the level of cultivation of the participants of the encounter" (Tryuk 2007: 99). In 2004, the International Association of Conference Interpreters (AIIC) also confirmed that 
$81 \%$ of staff interpreters and $70 \%$ of freelancers were highly satisfied with their profession. According to their 2005-2006 and 2009 surveys, the job satisfaction levels reached very high values, with almost $77 \%$ of the informants stating that they were highly satisfied with their work despite frequent mentions of a difficult job and stressful life. The results show that there is a positive correlation between age and the informants' degree of satisfaction: "the younger ( $\leq 40$ years) were more satisfied (over 83\%) than the average population (76.8\%)" (Liu 2011: 46).

4. "Overall job satisfaction will vary directly with the extent to which those needs of an individual which can be satisfied are actually satisfied; the stronger the need, the more closely will job satisfaction depend on its fulfillment" (Schaffer 1953: 3).

5. Ferguson, Donna (8 April 2015): The world's happiest jobs. The Guardian. Consulted 26 April 2017, <https://www.theguardian.com/money/2015/apr/07/going-to-work-with-a-smile-on-yourface $>$.

6. Smith, Jacquelyn (23 March 2012): The Happiest Jobs in America. Forbes. Consulted 26 April 2017, $<$ https://www.forbes.com/sites/jacquelynsmith/2012/03/23/the-happiest-jobs-inamerica/\#3d68287679e2>.

7. On comparison on rates per standard page in the majority of Slovak translators see Djovčoš (2014: 345).

8. Ministerstvo SPRAVodlivosti SR [Ministry of Justice of the Slovak Republic] (26 March 2004): Zákon č. 382/2004 Z. z. o znalcoch, tlmočníkoch a prekladateloch a o zmene a doplnení niektorých zákonov v znení neskorších predpisov [Act No. 382/2004 Coll. on Experts, Interpreters, and Translators and its later amendments]. Bratislava: Ministerstvo spravodlivosti SR [Ministry of Justice of the Slovak Republic]. Consulted 11 February 2018, <https://www.slov-lex.sk/pravnepredpisy/SK/ZZ/2004/382/>.

9. Ministerstvo SPRAVOdlivosti SR (23 August 2004): Vyhláška 490/2004 [Decree-Law 490/2004]. Bratislava: Ministerstvo spravodlivosti SR. Consulted 11 February 2018, <https://www.slov-lex.sk/ pravne-predpisy/SK/ZZ/2004/490/vyhlasene_znenie.html>.

10. Ministerstvo Spravodlivosti SR (23 August 2004): Vyhláška 491/2004 [Decree-Law 491/2004]. Bratislava: Ministerstvo spravodlivosti SR. Consulted 11 February 2018, <https://www.slov-lex.sk/ pravne-predpisy/SK/ZZ/2004/491/>.

11. Ministerstvo SPRAVodlivosti SR (23 November 2007): Zákon, ktorým sa mení a doplña zákon č. 382/2004 Z. z. o znalcoch, tlmočníkoch a prekladateloch a o zmene a doplnení niektorých zákonov $v$ znení zákona č. 93/2006 Z. z. [Act amending and supplementing Act No. 382/2004 Coll. on Experts, Interpreters, and Translators and its later Amendments, as amended by Act No. 93/2006 Coll.]. Bratislava: Ministerstvo spravodlivosti SR. Consulted 11 February 2018, <https://www. slov-lex.sk/pravne-predpisy/SK/ZZ/2007/522/>.

12. Ministerstvo SPRAVOdLivosti SR (1 January 2008): Zákon, ktorým sa mení a doplna zákon č. 222/2004 Z. z. o dani z pridanej hodnoty v znení neskoršich predpisov [Act amending and supplementing Act No. 222/2004 Coll. on Value Added Tax, as amended]. Bratislava: Ministerstvo spravodlivosti SR. Consulted 11 February 2018, <https://www.slov-lex.sk/pravne-predpisy/SK/

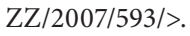

13. "Jednotný automatizovaný systém právnych informáciî" stands for "Unified Automated Legal Information." Ministerstvo SPRAVODLIVOSTI SR (Last update: 9 March 2010): Jednotnýautomatizovaný systém právnych informácií [Unified Automated Legal Information]. Consulted 28 February 2018, <www.jaspi.justice.gov.sk>.

14. Rakšányiová (2015) deals with a social space of sworn translators in contemporary Slovakia. See also Solová (2015) who discusses the situation of sworn translators in Poland from the point of view of their current training profile.

15. Pym, Anthony, Grin, François, Sfreddo, Claudio, et al. (24 July 2012): Studies on Translation and Multilingualism: The Status of the Translation Profession in the European Union. Brussels: European Commission. Consulted 1 March 2018, <https://www.scribd.com/document/215260219/Studieson-Translation-and-Multilingualism-The-Status-of-the-Translation-Profession-in-the-EuropeanUnion>.

16. "[...] we have the status of an official but in reality we are translators just as any other translators in the world" (Koskinen 2009: 96).

17. Click4Survey (www.click4survey.sk) is similar to Survio (www.survio.com) or Survey Monkey (www.surveymonkey.com), which also offer a number of filtering options to analyse data.

18. Our emphasis. 


\section{REFERENCES}

Abdallah, Kristiina (2010): Translator's Agency in Production Networks. In: Tuija Kinnunen and Kaisa Koskinen, eds. Translators' Agency. Tampere: Tampere University Press, 11-46.

BednÁrová-Gibová, Klaudia (2016): Towards an Understanding of EU Translation. Prešov: Prešov University. Consulted on 5 April 2017, <http://www.pulib.sk/web/kniznica/elpub/ dokument/Bednarova3>.

Chesterman, Andrew (2009): The Name and Nature of Translator Studies. Hermes. 42:13-22.

CHol, Jungwa (2007): Study on job satisfaction and directions for the training of conference interpreters. Forum. 5(2):23-38.

Cummins, Robert and Gullone, Eleonore (2000): Why we should not use 5-point Likert scales: The case for subjective quality of life measurement. In: Proceedings of the Second International Conference on Quality of Life in Cities. (2 ${ }^{\text {nd }}$ International Conference on Quality of Life in Cities, Singapore, 8-10 March 2000). Singapore: School of Building and Real Estate, National University of Singapore, 74-93.

Dam, Helle V. and Zethsen, Karen Korning (2008): Translator Status - A Study of Danish Company Translators. The Translator. 14(1):71-96.

Dam, Helle V. and Zethsen, Karen Korning (2009): Who Said Low Status? A Study on Factors Affecting the Perception of Translator Status. JoSTrans. 12:2-36.

Dam, Helle V. and Zethenen, Karen Korning (2011): The Status of Professional Business Translators on the Danish Market: A Comparative Study of Company, Agency and Freelance Translators. Meta. 56(4):976-997.

Dam, Helle V. and Zethsen, Karen Korning (2014): Translators in international organizations. A special breed of high-status professionals? Danish EU translators as a case in point. In: Claudia Angelelli, ed. The Sociological Turn in Translation and Interpreting Studies. Amsterdam/Philadelphia: John Benjamins, 93-113.

Dam, Helle V. and Zethenen, Karen Korning (2016): "I think it is a wonderful job." On the solidity of the translation profession. JoSTrans. 25:174-187.

Dam, Helle V. and Koskinen, Kaisa, eds. (2016): The Translation Profession: Centres and Peripheries. JoSTrans. 25.

Djovčoš, Martin (2012): Kto, čo a za akých podmienok prekladá: prekladatel'v kontexte doby [Who, what, how and under which circumstances translates: translators in the context of their time]. Banská Bystrica: Matej Bel University.

DJovčoš, Martin (2014): Translators and Social Context: The Case Study of Slovakia. Meta. 59(2):330-359.

Djovčoš, Martin and Šveda, Pavol (2017): Mýty a fakty o preklade a tlmočení na Slovensku [Myths and Facts about Translation and Interpreting in Slovakia]. Bratislava: Veda.

Ehrensberger-Dow, Maureen (2015): An Ergonomic Perspective of Professional Translation. Meta. 60(2):328.

Ehrensberger-Dow, Maureen (2017): An ergonomic perspective of translation. In: John W. Schwieter and Aline Ferreira, eds. The Handbook of Translation Studies and Cognition. Hoboken: John Wiley \& Sons, 332-349.

Ehrensberger-Dow, Maureen and Massey, Gary (2013): Indicators of translation competence: Translators' self-concepts and the translation of titles. Journal of Writing Research. 5(1):103131.

Ehrensberger-Dow, Maureen, Hunziker Heeb, Andrea, Massey, Gary, et al. (2016): An International Survey of the Ergonomics of Professional Translation. ILCEA [online](27). Consulted on 3 March 2018, <https://journals.openedition.org/ilcea/4004\#text>.

Godвоuт, Marielle (2016): Lack of status-are translators the authors of their own misfortune? Circuit. 131. Consulted 4 March 2018, <https://www.circuitmagazine.org/dossier-131/lackof-status-are-translators-the-authors-of-their-own-misfortune $>$.

Henter, Sarah (2016): How Happy are Translators with their Studies? Current Trends in Translation Teaching and Learning. 3:24-66. 
Hermans, Johan and Lambert, José (1998/2006): From translation markets to language management: The implications of translation services. In: Dirk Delabastita, Lieven D'Hulst, and Reine Meylaerts, eds. Functional Approaches to Culture and Translation: Selected Papers by José Lambert. Amsterdam/Philadelphia: John Benjamins, 147-162.

Hubscher-Davidson, Séverine (2016): Trait Emotional Intelligence and Translation: A Study of Professional Translators. Target. 28(1):132-157.

Katan, David (2009): Translation theory and professional practice: A global survey of the great divide. Hermes. 42:111-153.

Katan, David (2011): Occupation or Profession. A Survey of the Translators' World. In: Rakefet Sela-Sheffy and Miriam Shlesinger, eds. Identity and Status in the Translational Professions. Amsterdam/Philadelphia: John Benjamins, 65-88.

Koskinen, Kaisa (2008): Translating Institutions: An Ethnographic Study of EU Translation. Manchester: St. Jerome.

Koskinen, Kaisa (2009): Going Localized, Getting Recognized. The Interplay of the Institutional and the Experienced Status of Translators in the European Commission. Hermes. 42:93-110.

LIU, Fung-Ming Christy (2011): A Quantitative and Qualitative Enquiry into Translators' and Job-related Happiness: The Case of Greater China. Doctoral dissertation, unpublished. Tarragona: Universitat Rovira i Virgili.

LiU, Fung-Ming Christy (2013): A Quantitative Enquiry into the Translator's Job-related Happiness: Does Visibility Correlate with Happiness? Across Languages and Cultures. 14(1):123147.

MüGlová, Daniela (2009): Komunikácia, tlmočenie, preklad, alebo Prečo spadla Babylonská veža? [Communication, Interpreting, Translation or Why the Tower of Babel Collapsed]. Bratislava: Enigma.

Ollivier, Michèle (2000): Too Much Money off Other People's Backs: Status in Late Modern Societies. The Canadian Journal of Sociology. 25(4):441-470.

PöchHACKer, Franz (2009): Conference interpreting. Surveying the profession. Translation and Interpreting Studies. 4(2):172-186.

RAKŠÁNYIOVÁ, Jana (2015): Sociálny priestor súčasného právneho prekladu na Slovensku [A Social Space of Contemporary Legal Translation in Slovakia]. In: Jana RAKšÁNYIOvÁ, ed. Úradný prekladatel'v slovenskom a európskom sociálnom priestore [A Sworn Translator in a Slovak and European Social Space]. Bratislava: Univerzita Komenského, 7-55.

Rodríguez-Castro, Mónica (2015): Conceptual construct and empirical validation of a multifaceted instrument for translator satisfaction. Translation \& Interpreting. 7(2):30-50.

Ruokonen, Minna (2013): Studying Translator Status: Three Points of View. In: Maria Eronen and Marinella RodI-RIsBerg, eds. Haasteena näkökulma/Perspektivet som utmaning/Point of view as Challenge/ Perspektivität als Herausforderung. (VAKKI-symposiumi XXXIII, Vaasa, 7-8 February 2013) Vaasa: VAKKI, 327-338.

SCHAFFER, Robert (1953): Job satisfaction as related to need satisfaction in work. Psychological Monographs. 67:1-29.

Sela-Sheffy, Rakefet (2010): 'Stars' or 'professionals': the imagined vocation and exclusive knowledge of translators in Israel. In: Esther Monzó and Oscar Diaz Fouces, eds. Applied Sociology in Translation Studies. MonTI. 2:131-152.

Sela-Sheffy, Rakefet and Shlesinger, Miriam (2008): Strategies of Image-Making and Status Advancement of Translators and Interpreters as a Marginal Occupational Group. In: Anthony Pym, Miriam Shlesinger, and Daniel Simeoni, eds. Beyond Descriptive Translation Studies: Investigations in Homage to Gideon Toury. Amsterdam/Philadelphia, 79-90.

Sela-Sheffy, Rakefet and Shlesinger, Miriam (2011): Identity and Status in the Translational Professions. Amsterdam/Philadelphia: John Benjamins.

Setton, Robin and Guo Liangliang, Alice (2011): Attitudes to Role, Status and Professional Identity in Translators and Interpreters with Chinese in Shanghai and Taipei. In: Rakefet Sela-Sheffy and Miriam Shlesinger, eds. Identity and Status in the Translational Professions. Amsterdam/Philadelphia: John Benjamins, 89-118. 
Snell-Hornby, Mary (2006): The Turns of Translation Studies. New Paradigms or Shifting Viewpoints? Amsterdam/Philadelphia: John Benjamins.

Solové, Regina (2015): The Polish sworn translator: current training profile and perspectives. The Interpreter and Translator Trainer. 9(2):243-259.

Tryuk, Malgorzata (2007): Community interpreting in Poland. In: Cecilia Wadensjö, Birgitta Englund Dimitrova, and Anna-Lena Nilsson, eds. The Critical Link 4: Professionalisation of Interpreting in the Community. Amsterdam/Philadelphia: John Benjamins, 95-106.

Veenhoven, Ruut (1997): Advances in Understanding Happiness. Revue québécoise de psychologie. 18:29-74.

Venuti, Lawrence (1995): The Translator's Invisibility. A History of Translation. London/New York: Routledge.

Volland, Nicolai (2014): The Birth of a Profession: Translators and Translation in Modern China. In: Hsiao-Yen Peng and Isabelle Rabut, eds. Modern China and the West: Translation and Cultural Mediation. Leiden: Brill, 126-150.

WARR, Peter (2007): Work, Happiness, and Unhappiness. Mahwah: Lawrence Erlbaum.

Weiss-Gal, Idit and Welbourne, Penelope (2008): The Professionalization of Social Work: A Cross-national Exploration. International Journal of Social Welfare. 17:281-290. 